\title{
RESPONSE OF TWO ORNAMENTAL PALM GENERA TO SOME FERTILIZATION TREATMENTS
}

\author{
Reem M. Said; Gehan H. Abdel-Fattah and A.S. Tawila
}

Botanical Gardens Res. Dept., Hort. Res. Inst., ARC, Giza, Egypt.

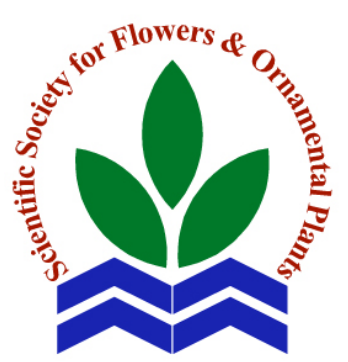

Scientific J. Flowers \& Ornamental Plants, 1(2):117-135 (2014).

Received:

$21 / 8 / 2014$

Revised by:

Prof. Dr. E.S. Nofal, Kafr El-Sheikh Univ.

Prof. Dr. S.M. Shahin, Hort. Res. Inst., ARC.
ABSTRACT: In a trial to improve the growth of two economic ornamental palms i.e. Butia capitata (Mart.) and Livistona decipiens (Becc.) at the early growth stages, an investigation was consummated throughout two successive seasons (2011 and 2012) at the nursery of Horticulture Research Institute, Giza, Egypt to study the effect of bioand chemical fertilization with different rates on growth and chemical constituents of the two ornamental palms. Two years old transplants of both palms were cultured on April, $1^{\text {st }}$ in both seasons. The biofertilizer of phosphorene with different rates $(2,4$ and $6 \mathrm{~g} / \mathrm{pot})$, the mixture of $\mathrm{N}, \mathrm{P}$ and $\mathrm{K}(1: 1: 1)$ used at $1.5,2.5$ and $3.5 \mathrm{~g} /$ pot and the commercial product of Grow more at $0.5,1.5$ and $2.5 \mathrm{ml} / 1$ were used in both seasons. All of them were added at monthly interval commencing from May, $1^{\text {st }}$ to October, $1^{\text {st }}$. The results emphasized that all fertilization treatments improved vegetative growth, root parameters and chemical constituent of leaves. However, the effect was differed according to the different treatments used. Applying phosphorene at $6 \mathrm{~g} /$ pot and Grow more at $1.5 \mathrm{ml} / \mathrm{l}$ gave the utmost high values of vegetative growth parameters of Butia capitata, whereas plants of Livistona decipiens treated with $4 \mathrm{~g} /$ pot phosphorene was the best in improving such parameters in the two seasons. Treating plants with either NPK at 3.5 $\mathrm{g} /$ pot or Grow more at $0.5 \mathrm{ml} / 1$ proved their superiority in raising root length and fresh and dry weight of roots for Butia capitata. Meanwhile, results of Livistona decipiens indicated that treating plants with phosphorene at the lowest rate $(2 \mathrm{~g} / \mathrm{pot})$ was the best for improving root traits in most cases expressed as number of roots/plant and fresh and dry weights of roots.

Chemical constituents of leaves were also affected by the different fertilization treatments. A clear increment in either chlorophyll (a) or carotenoids accumulation in leaves of Butia capitata was observed due to applying the highest rate of phosphorene (6 g/pot) and the lowest one of Grow more $(0.5 \mathrm{ml} / \mathrm{l})$. However, using Grow more at $0.5 \mathrm{ml} / 1$ gave also the utmost high value of chlorophyll (b) in leaves of the same species. For Livistona decipiens, applying Grow more at the lowest and moderate rates $(0.5$ and $1.5 \mathrm{ml} / \mathrm{l})$ registered the highest values of chlorophyll (a) accumulation in the leaves. Meanwhile, using the lowest Grow more rate $(0.5 \mathrm{ml} / \mathrm{l})$ was the best for raising carotenoids content. Meanwhile, using the highest level of NPK (3.5 g/pot) proved its mastery in elevating chlorophyll (b) in the leaves.

As for chemical constituents in leaves concerning Butia capitata, results revealed that using the lowest rate of phosphorene and NPK ( $2 \mathrm{~g} /$ pot and $1.5 \mathrm{~g} /$ pot, respectively), as well as the highest one of NPK ( $3.5 \mathrm{~g} / \mathrm{pot})$ beside the moderate and the highest rates of Grow 
more ( 1.5 and $2.5 \mathrm{ml} / 1$, respectively) were the best treatments for raising $\mathrm{N} \%$ in the leaves. Meanwhile, applying the lowest level of either NPK $(1.5 \mathrm{~g} /$ pot $)$ or Grow more $(0.5 \mathrm{ml} / \mathrm{l})$ gave the greatest values of $\mathrm{N} \%$ in the leaves of Livistona decipiens. Also, $\mathrm{P} \%$ revealed a positive influence as a result of treating Butia capitata plant with Grow more at the highest rate $(2.5 \mathrm{ml} / \mathrm{l})$, whereas, $\mathrm{P}$ content in Livistona decipiens leaves was the highest by applying the moderate NPK rate $(2.5 \mathrm{~g} / \mathrm{pot})$. In the same time, the moderate and the highest rates of phosphorene (4 and $6 \mathrm{~g} / \mathrm{pot}$ ) and the highest one of NPK (3.5 g/pot) were the best treatments used for elevating $\mathrm{K} \%$ in Butia capitata leaves. Meanwhile, treating plants with phosphorene at $2 \mathrm{~g} / \mathrm{pot}$ and Grow more at $0.5 \mathrm{ml} / 1$ and $2.5 \mathrm{ml} / 1$ succeeded to produce the highest accumulation rate of $\mathrm{K} \%$ in Livistona decipiens leaves. In addition, treating plants with the highest phosphorene rate $(6 \mathrm{~g} / \mathrm{pot})$ proved its superiority for elevating total carbohydrates content in the leaves of either Butia capitata or Livistona decipiens palms.

From the aforementioned results, it could be recommended to use either phosphorene at 4-6 g/pot or Grow more at $0.5-1.5 \mathrm{ml} / 1$ for improving quality and growth traits of the two genera of palms used in this work.

Key words: Butia capitata, Livistona decipiens, ornamental palms, bio- and chemical fertilization, vegetative and root growth and chemical composition.

\section{INTRODUCTION}

Palms represent one of the most important elements in tropical, subtropical and Mediterranean landscapes. They belong to the Arecaceae (Palmaceae) family. Commercial palm production for landscape and interiorscape purposes has become one of the largest segments of the ornamental horticulture industry (Tisserat, 1984 and Litz et al., 1985). Many of them are excellent indoor plants and have been used in this way for a long time. Recently, people businessmen are well aware of the decorative value of plants indoor and there is a wide range of palms available for selection.

Butia capitata (Mart.), Pindo palm also known as jelly palm is native to Argentina, Brazil and Uruguay. Such palm is one of the most popular palms in the world because of its stunning appearance, cold hardiness and bright yellow fruit, that can be made into a Jelly, its graceful appearances with bluegreen fronds make it great for pool-side plantings, and also for container use. Butia is one of the most popular Florida palm trees which can live up to 80 years (GRIN, 2011).

Livistona decipiens (Becc.), is known as ribbon fan palm planted as a single specimen, but is much more attractive in groups of three or more individuals of varying heights. It needs space and high light levels indoors (Riffle and Craft, 2003). It's endemic to the eastern Queensland coastal region of Australia.

Mineral nutrition is one of the most important aspects of palm culture although micro-nutrients are needed relatively in very small quantities for foliage plants, their deficiency or excess cause great disorders in the different physiological processes of plants (Marschner, 1995).

Chemical fertilization, especially NPK promotes the vegetative growth. Nitrogen is the most effective element, since it is an essential constituent of proteins, some vitamins and co-enzymes. Phosphorus is closely concerned with the vital growth processes in plants. Potassium plays an important role in metabolism such as the 
formation of carbohydrates and protein, the regulation of water conditions within the plant cell (Jain, 1983). This true was proved by El-Shakhs (2002) on Livistona chinensis who adviced to apply $2 \mathrm{~g}$ of the Newstar or Osmocote fertilizer to obtain good healthy palm. Likewise, Agina et al. (2005) mentioned that foliar fertilization with Kristalon improved vegetative growth as well as pigments and minerals content in the leaves of Ficus macrocarpa-nitida. Similar observations were also noticed by El-Sayed et al. (2010) and Hashish (2011) who worked on Vinca rosea and Paulownia kawakamii, respectively and indicated that all vegetative and root growth parameters were markedly improved in response to the various NPK fertilization treatments.

Biofertilizers are microbial inoculants used for increasing soil fertility with microorganisms to accelerate certain microbial processes, such microbiological processes can change unavailable forms of nutrients into available ones that can be easily assimilated by plants (Subba Rao, 2001). Phosphorene is one of biofertilizers which converts the phosphorus complex to an available phase. Many efforts, however have been done in this respect, as Abd-Rabou (2006) who stated that the effect of phosphorene and microbine alone or in combination clearly increase vegetative growth parameters of avocado and mango seedlings. On Peperomia obtusifolia, ElSayed et al. (2007) revealed that nitrobien fertilization at $5 \mathrm{~g} /$ pot plus $\mathrm{GA}_{3}$ at $1000 \mathrm{ppm}$ gave the best vegetative and root growth coupled with the highest content of internal constituents. El-Attar (2011) on Chamaedorea elegans proved that phosphorene, nitrobactrene and mycorrhizae were the best for number and weight of leaves as well as the content of chlorophylls, $\mathrm{K}$ and carbohydrates in the leaves. In the same year (2011), Hashish confirmed these results on Paulownia kawakamii seedlings.

Therefore, this experimental trial was performed on two important economic ornamental palms i.e. Butia capitata and
Livistona decipiens aiming to improve their qualities under local conditions in Egypt because adequate information are not available on the effect of fertilization treatments on most palm plants; especially at early growth stages.

\section{MATERIALS AND METHODS}

The experimental trial was consummated throughout two successive seasons (2011 and 2012) at the nursery of Horticulture Research Institute, Giza, Egypt on two economic ornamental palms i.e. Butia capitata (Mart.) and Livistona decipiens (Becc.). It intended to find out the response of these palms to different types of fertilization i.e. bio- and chemical fertilization (phosphorene, the mixture of NPK and Grow more) for achieving the hope of producing palms of high quality at the early growth stages.

\section{Materials:}

- Two years old transplants of Butia capitata (Mart.) (20-25 cm in height and 1-2 leaves) and Livistona decipiens (Becc.) (30-35 cm in height and 3-4 leaves) were used in the two seasons.

- Plastic pots of 30-cm-diameter filled with about $3 \mathrm{~kg}$ of an equal mixture of sand, clay and peatmoss $(1: 1: 1, \mathrm{v} / \mathrm{v} / \mathrm{v})$. Some physical and chemical properties of sand, clay and peatmoss are exhibited in Tables ( $a$ and $b$ ).

- Different fertilization types of phosphorene, a mixture of $\mathrm{N}, \mathrm{P}$ and $\mathrm{k}$ and Grow more were used in the two seasons. The mixture of NPK $(1: 1: 1)$ was prepared from ammonium sulphate $(20.5 \% \mathrm{~N})$, calcium super phosphate $\left(\begin{array}{llll}15.5 & \% & \mathrm{P}_{2} \mathrm{O}_{5}\end{array}\right)$ and potassium sulphate $\left(48.5 \% \mathrm{~K}_{2} \mathrm{O}\right)$. The ratio of $1: 1: 1$ was mathematically calculated according to the effective nutrient elements of fertilizers. Biofertilization with phosphorene (a commercial product which contains a special clone of bacteria which changes the unavailable triphosphate to available monophosphate). The commercial fertilizer 
Reem M. Said et al.

Table a. Some physical and chemical properties of the used sand and clay in both seasons.

\begin{tabular}{|c|c|c|c|c|c|c|c|c|c|c|c|c|c|c|}
\hline \multirow{2}{*}{$\frac{\stackrel{D}{2}}{\stackrel{D}{0}}$} & \multicolumn{4}{|c|}{$\begin{array}{c}\text { Particle size } \\
\text { distribution(\%) }\end{array}$} & \multirow{2}{*}{ S.P } & \multirow{2}{*}{$\begin{array}{c}\text { E.C } \\
(\mathrm{ds} / \mathrm{m})\end{array}$} & \multirow{2}{*}{ pH } & \multicolumn{4}{|c|}{ Cations (meq/L) } & \multicolumn{3}{|c|}{ Anions(meq/L) } \\
\hline & $\begin{array}{l}\text { Coarse } \\
\text { sandy }\end{array}$ & $\begin{array}{l}\text { Fine } \\
\text { sand }\end{array}$ & Silt & Clay & & & & $\mathbf{C a}^{++}$ & $\mathbf{M g}^{++}$ & $\mathbf{N a}^{+}$ & $\mathbf{K}^{+}$ & $\mathrm{HCO}_{3}^{-}$ & $\mathrm{Cl}^{-}$ & $\mathrm{SO}_{4}{ }^{-}$ \\
\hline Sand & 18.72 & 71.28 & 4.76 & 5.24 & 21.83 & 1.58 & 8.20 & 2.65 & 2.48 & 21.87 & 0.78 & 3.85 & 13.00 & 10.93 \\
\hline Clay & 7.46 & 16.75 & 34.53 & 40.89 & 41.76 & 2.18 & 8.33 & 16.93 & 9.33 & 20.44 & 0.37 & 3.82 & 1.46 & 41.79 \\
\hline
\end{tabular}

Table b. Some physical and chemical properties of the used peatmoss in both seasons.

\begin{tabular}{llll}
\hline Organic matter & $90-95 \%$ & $\mathbf{N}$ & $1.09 \%$ \\
Ash & $5-10 \%$ & $\mathbf{P}$ & $0.23 \%$ \\
Density (vol. dry) & $80-90 \mathrm{mg} / \mathrm{L}$ & $\mathbf{K}$ & $1.77 \%$ \\
pH value & 3.4 & $\mathbf{F e}$ & $421 \mathrm{ppm}$ \\
Water relation capacity & $60-75 \%$ & $\mathbf{M n}$ & $72 \mathrm{ppm}$ \\
Salinity & $0.3 \mathrm{~g} / 1$ & $\mathbf{Z n}$ & $41 \mathrm{ppm}$ \\
\hline
\end{tabular}

of Grow more as a liquid foliar fertilizer contains several macro and micro elements, Table (c).

Table c. Some chemical properties of the used commercial fertilizer (Grow more) in both seasons.

\begin{tabular}{llll}
\hline $\mathbf{N}$ & $8 \%$ & $\mathbf{Z n}$ & $0.15 \%$ (citric) \\
$\mathbf{P}_{2} \mathbf{O}_{5}$ & $3 \%$ & $\mathbf{M g}$ & $0.15 \%$ (citric) \\
$\mathbf{K}_{2} \mathbf{O}$ & $6 \%$ & $\mathbf{S O}$ & $0.01 \%$ \\
$\mathbf{C a}$ & $0.02 \%$ & $\mathbf{B o}$ & $0.01 \%$ \\
$\mathbf{F e}$ & $0.15 \%$ (citric) & $\mathbf{M o}$ & $0.01 \%$ \\
$\mathbf{M n}$ & $0.15 \%$ (citric) & & \\
\hline
\end{tabular}

\section{Procedure:}

The two years old transplants of both palms were cultured on April, $1^{\text {st }}$ in both seasons in the plastic pots (one transplant/pot). After one month (on May, $1^{\text {st }}$ ), the transplants were monthly subjected to the following treatments till the end of the experiment on October, $1^{\text {st. }}$ :

1. No fertilization, referred to as control.

2. Biofertilization with phosphorene at the rates of 2, 4 and $6 \mathrm{~g} /$ pot.

3. Chemical fertilization with a mixture of NPK at the rates of 1.5, 2.5 and $3.5 \mathrm{~g} /$ pot

4. The commercial fertilizer of Grow more as a liquid foliar fertilizer which sprayed on the foliage till run-off at the rates of $0.5,1.5$ and $2.5 \mathrm{ml} / 1$ water.
The three rates of the different fertilizers were referred to as low, medium and high, respectively. The layout of the experiment in the two seasons was a completely randomized design (Mead et al., 1993) for each palm type with three replicates, as each replicate contained three plants. In addition, the regular agricultural practices necessary for such plantation were also done whenever needed.

At the end of each season (on October, $30^{\text {th }}$ ), data were recorded as follows: plant height $(\mathrm{cm})$, number of leaves/plant, root length $(\mathrm{cm})$ for the longest root, number of roots/plant and fresh and dry weights $(\mathrm{g})$ of vegetative parts and roots/plant. However, in the second season only samples from the fourth leaf were taken to determine the content of photosynthetic pigments (chlorophyll a, b and carotenoids as $\mathrm{mg} / \mathrm{g}$ f.w.) according to the method of Moran (1982). While, in dry samples, the percentages of total carbohydrates (Herbert et al., 1971), nitrogen (N) using microkjeldahl method as described by Pregl (1945), phosphorus (P) colorimetrically as the method explained by Watanabe and Olsen (1965) and potassium (K) using Flame-photometer set (Jackson, 1973) were evaluated. 
Data were then tabulated and subjected to analysis of variance according to SAS Institute program (1994) and the New LSD method at $5 \%$ level (Mead et al., 1993) was employed to verify the significancy level among means of the various treatments.

\section{RESULTS AND DISCUSSION}

\section{Effect of bio- and chemical fertilization on vegetative growth parameters of Butia capitata.}

Generally, it could be mentioned from data registered in Table (1) that all fertilization treatments gave rise to all vegetative growth parameters comparing with that gained from control plants with significant effects in most cases in both seasons. However, the different treatments differed in their effects on the same traits. In this connection, the obtained values indicated the prevalence of applying phosphorene at $6 \mathrm{~g} /$ pot and Grow more at 1.5 $\mathrm{ml} / \mathrm{l}$ for improving vegetative growth parameters as they gave the utmost high values in most cases in both seasons. The second category in raising the same parameters was occupied by plants treated with NPK at $2.5 \mathrm{~g} /$ pot and Grow more at 0.5 $\mathrm{ml} / \mathrm{l}$. However, phosphorene treatment at 4 $\mathrm{g} /$ pot also elevated vegetative growth parameters and occupied the third position in this concern, but in the second season only. Meanwhile, the other fertilization treatments gave an intermediate effect in this respect.

\section{Effect of bio- and chemical fertilization on vegetative growth parameters of Livistona decipiens.}

Results of Table (2) show beneficial effects on the different vegetative growth parameters studied due to applying all fertilization treatments in both seasons. However, treating plants with phosphorene at the moderate rate $(4 \mathrm{~g} / \mathrm{pot})$ proved its mastery in improving the different vegetative growth characters studied in the two seasons with significant effect comparing with control and occupied the first category in this regard. Meanwhile, supplying plants with phosphorene at $6 \mathrm{~g} /$ pot, NPK at $3.5 \mathrm{~g} /$ pot and
Grow more at $1.5 \mathrm{ml} / \mathrm{l}$ revealed also great influence in improving vegetative growth traits in most cases and belonged to the second rank. The other treatments used gave an intermediate effect on the same parameters.

The aforementioned results show clearly the prevalence of applying bio- and chemical fertilization (phosphorene, NPK and Grow more) in improving vegetative growth parameters. This true might be attributed to their content of macro and micro elements, besides the role of biofertilizer which contains certain organisms (inoculation), capable of increasing soil fertility with micro-organisms to accelerate certain microbial processes, which can change unavailable forms of nutrients into available ones and can be easily assimilated by plants (Subba Rao, 2001). Also, it is well known that macro elements such as $\mathrm{N}, \mathrm{P}$ and k play a major role in growth and development of plants. Nitrogen $(\mathrm{N})$ is a main constituent of all proteins and nucleic acids, as well as, of both structural and non structural components of plant cells. Besides, involving phosphorus $(\mathrm{P})$ in energy transfer process and building of phospholibids and nucleic acids (Yeonhee et al., 2000). In addition, potassium $(\mathrm{K})$ is the factor affecting many functions of plants, stomata movement, regulating photosynthesis, respiratory rate and activating many enzymes involved in plant growth. It also increases protein synthesis and different metabolic processes, as well as reducing respiration, hence energy losses (Csirzinsky, 1999). Micro nutrients play also an important role in most vital processes of plants (Marschner, 1995) for example zinc is essential for plant metabolism (as an activator of several enzymes) of carbohydrates, protein, phosphate, RNA synthesis and tryptophan, chlorophyll synthesis, photosynthesis as well as its role as a co-factor of various enzymes (Mohr and Schopfer, 1995). Manganese plays a role in regulating the level of auxin, in photosynthetic apparatus synthesis (Marschner, 1995). 
Reem M. Said et al.

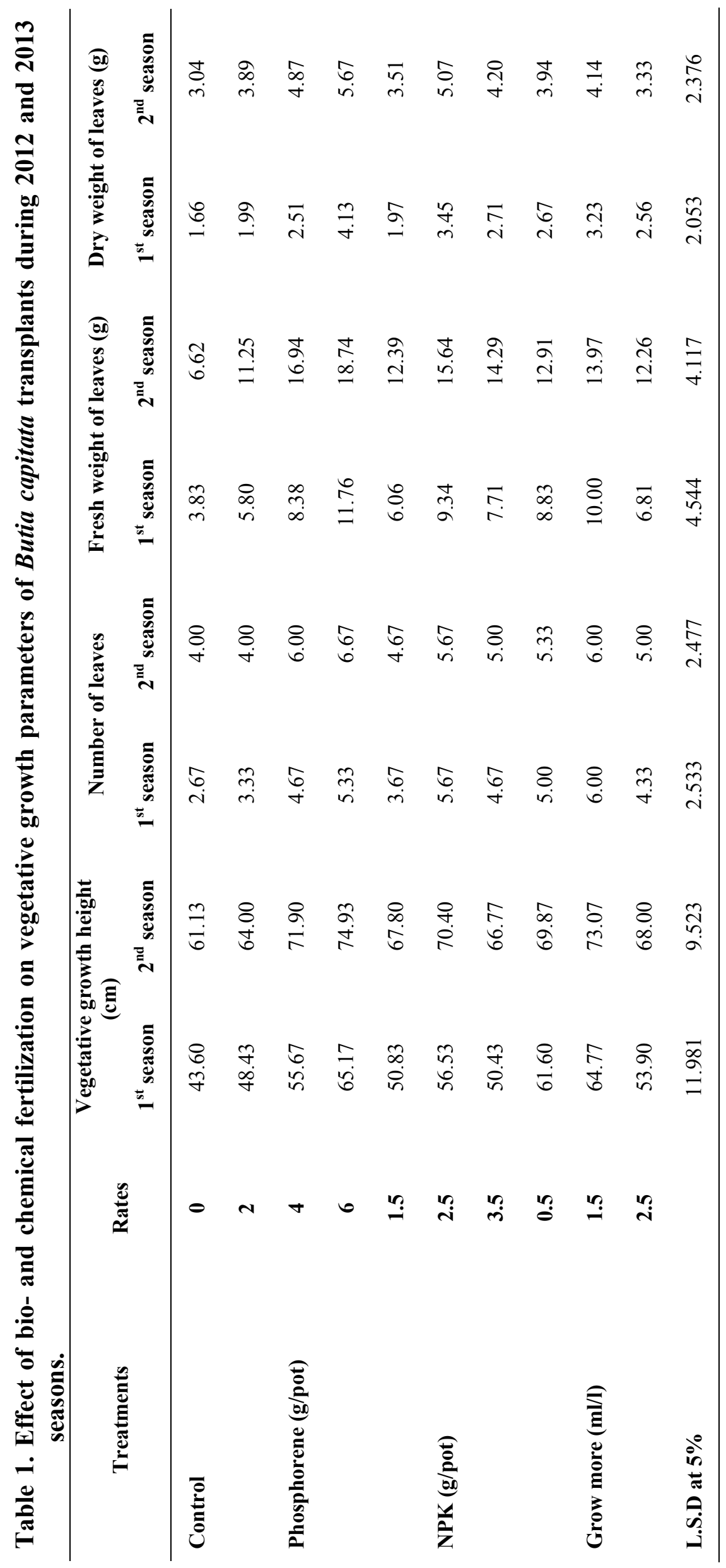


Scientific J. Flowers \& Ornamental Plants, 1(2):117-135 (2014)

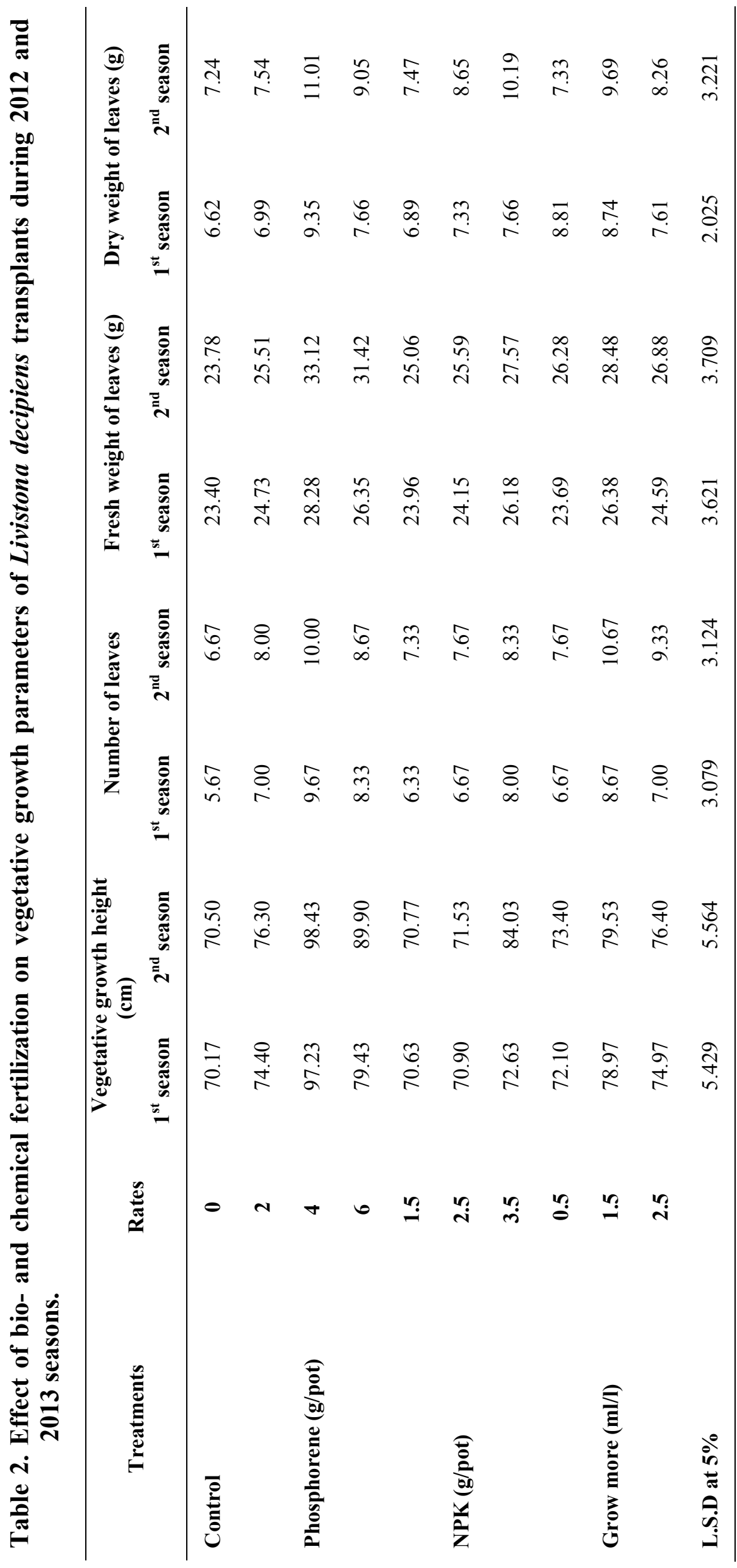


It is also thought to be involved in the destruction or oxidation of indole acetic acid (IAA), a natural auxin of plants (Goldacre, 1961).

Similar observations were also obtained by Jaiti (2007) who found that all arbuscular mycorrhizal (AM) fungi stimulated significantly shoot height, number of leaves/plant and fresh and dry weight of leaves of date palm (Phoenix dactylifera, L). El-Khateeb et al. (2010) on Chamaedorea elegans concluded that, phosphorene at 5 $\mathrm{g} /$ pot gave the thickest stem diameter, encouraged the formation of leaves, giving the heaviest leaves. With respect to the effect of chemical fertilization, the obtained results were also ascertained by many researches, El-Attar (2011) stated that biofertilizers greatly improved the vegetative growth of Chamaedorea elegans seedlings as the application of hemogreen (algae) gave the tallest plants and increased leaves formation followed by nitrobactrene and mycorrhizae. Hashish (2011) on Paulownia kawakamii found that microbein peatmoss $+75 \mathrm{~g} \mathrm{NPK}$ increased number of leaves. With respect to the effect of chemical fertilization, Petterson et al. (2008) on lady palm (Rhapis excelsa) seedlings studied the effect of different types of NPK fertilization (granulated fertilizer (10:10:10), foliar fertilization and commercial product Biofert (8:9:9). Results indicated that foliar fertilization significantly increased all plant growth parameters. Heider (2010) on Dracaena marginata mentioned that Kristalon at 1, 2 and $4 \mathrm{~g} /$ plant increased all growth parameters. Hashish (2011) on Paulownia kawakamii seedlings. Revealed that the vegetative growth responded positively to all NPK rates compared to control. Habib (2012) on Caryota mitis reported that using NPK at 4 $\mathrm{g} /$ pot gave the tallest plants, thickest shoots and highest number of leaves.

\section{Effect of bio- and chemical fertilization on root parameters of Butia capitata.}

Data outlined in Table (3) reveal that the different fertilization treatments improved most root parameters in both seasons (expressed as root length and fresh and dry weights of roots). In this respect, treating plants with either NPK at $3.5 \mathrm{~g} /$ pot or Grow more at $0.5 \mathrm{ml} / 1$ proved their superiority in raising the previous traits, with significant effects comparing with that registered from control in both seasons achieving the first rank in this concern. Meanwhile, supplying plants with phosphorene at $6 \mathrm{~g} /$ pot achieved the second rank in improving either fresh or dry weight of roots. However, the same degree was occupied by treating plants with phosphorene at the lowest rate $(2 \mathrm{~g} / \mathrm{pot})$ in raising root length in both seasons. Meanwhile, No. roots/plant was not significantly affected by the various treatments used in both seasons. The other treatments, on the other side, gave intermediate effects in this regard.

\section{Effect of bio- and chemical fertilization on root parameters of Livistona decipiens.}

Data scored in Table (4) clearly indicate that the different fertilization treatments caused an increment in all root parameters studied with significant effects comparing with control means in most cases. However, it could be mentioned that treating plants with phosphorene at the lowest rate $(2 \mathrm{~g} / \mathrm{pot})$ was the best treatment used in most cases for improving root traits and achieved the first position in raising the registered values in both seasons. Meanwhile, supplying plants with phosphorene at $4 \mathrm{~g} / \mathrm{pot}$, NPK at 2.5 $\mathrm{g} /$ pot and Grow more at $0.5 \mathrm{ml} / 1$ showed also a favourable effect on improving most root traits, especially root length and occupied the second rank in most cases. In the same time, the other fertilization treatments gave an intermediate effect in this concern.

The previous results indicated the beneficial effect of supplying plants with either bio or chemical fertilization for improving root parameters. However, many authors confirmed such effect on many palm plants and other species. Concerning the effect of biofertilizers Jaiti (2007) found that all arbuscular mycorrhizal (AM) fungi significantly stimulated fresh and dry weight of roots of date palm (Phoenix dactylifera L.). 
Scientific J. Flowers \& Ornamental Plants, 1(2):117-135 (2014)

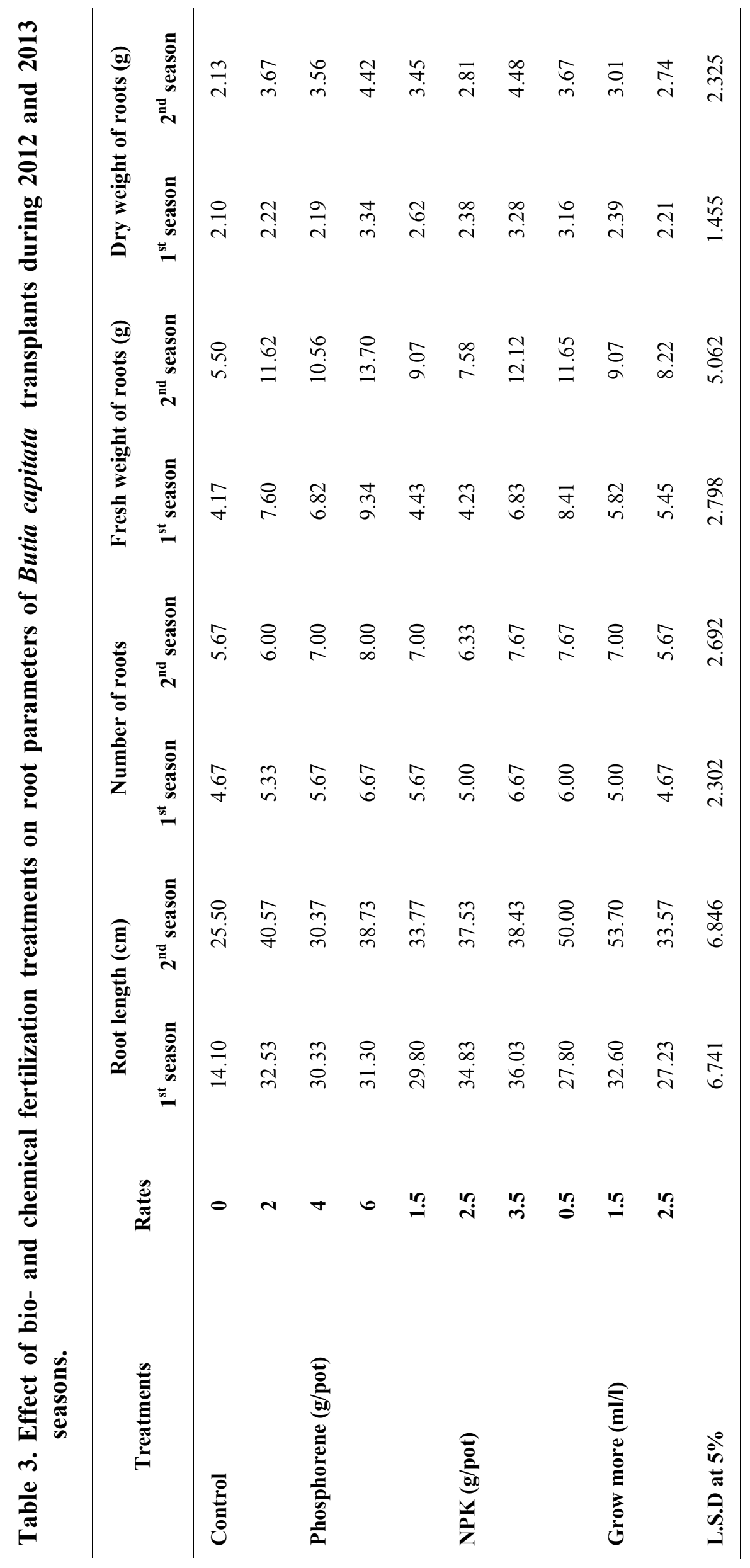


Reem M. Said et al.

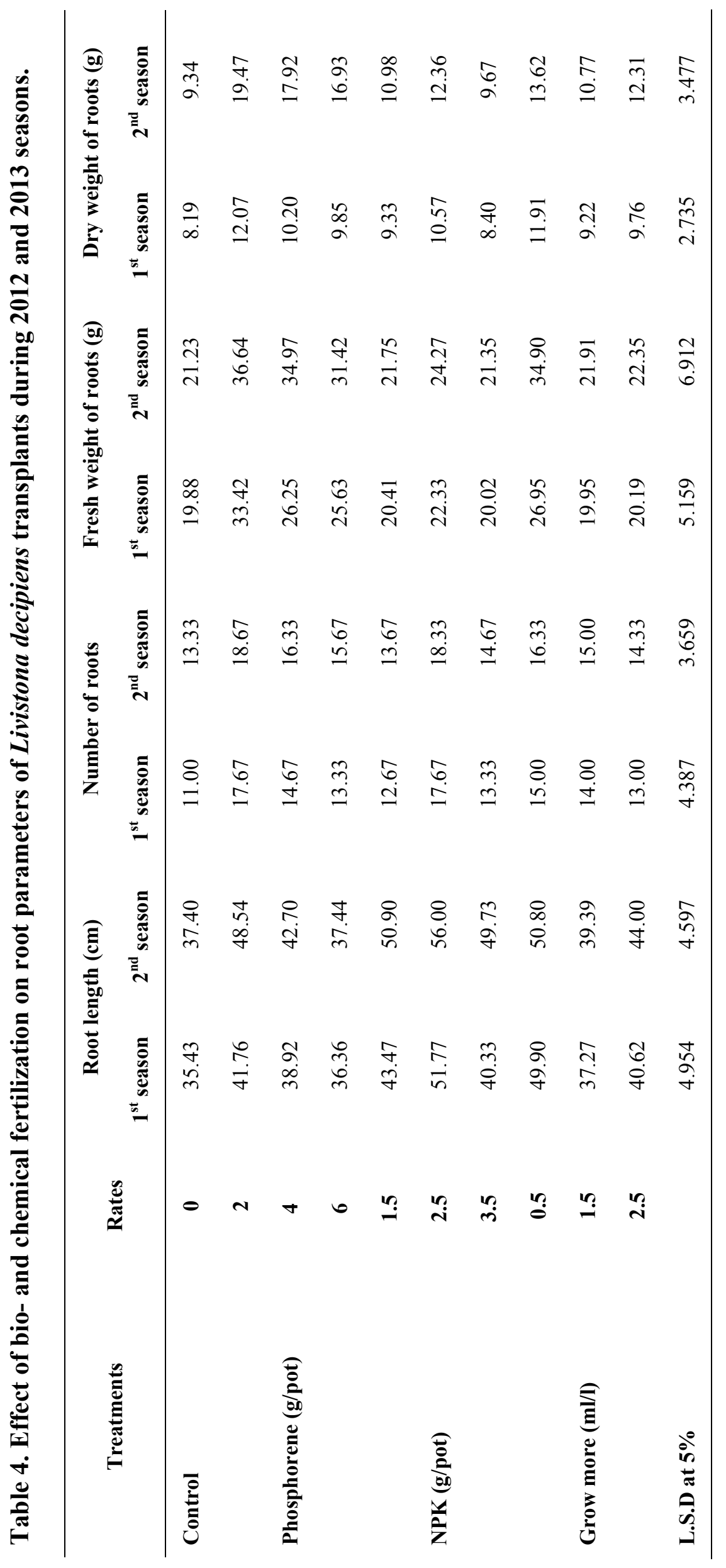


El-Khateeb et al. (2010) on Chamaedorea elegans concluded that, phosphorene at $5 \mathrm{~g} / \mathrm{pot}$ significantly increased the fresh and dry weight of roots. El-Attar (2011) on Chamaedorea elegans seedlings reported that phosphorene increased growth of roots. With respect to the effect of chemical fertilization a lot of workers recorded the beneficial effect of chemical fertilization on root parameters. Petterson et al. (2008) on lady palm (Rhapis excelsa) found that foliar fertilization with NPK (10:10:10) resulted in significant increment in all plant growth parameters. Heider (2010) added that Kristalon at 1, 2 and $4 \mathrm{~g} /$ plant increased all growth parameters of Dracaena marginata. Hashish (2011) investigated the effect of NPK fertilizer on Paulownia kawakamii seedlings. The vegetative growth responded positively to all NPK rates compared to control. Habib (2012) on Caryota mitis reported that using NPK at $4 \mathrm{~g}$ /pot was the most effective on increasing the fresh and dry weight of roots.

\section{Effect of bio- and chemical fertilization on chemical constituents of Butia capitata leaves (Table, 5):}

\section{1- Effect on pigments content:}

\section{a- Chlorophyll (a) content (mg/g f.w.):}

A clear increment in chlorophyll (a) in the leaves was noticed due to applying the different types of fertilization treatments compared with control, but, they differed in their effects according to the different treatments used. In this connection, great influence was observed due to supplying plants with phosphorene at $6 \mathrm{~g} /$ pot and Grow more at $0.5 \mathrm{ml} / 1$, registering the utmost high values, in this regard and occupied the first rank in raising such pigment. The second rank for elevating the same constituent was achieved by plants which received phosphorene at $2 \mathrm{~g} / \mathrm{pot}$ and those treated with Grow more at either 1.5 or $2.5 \mathrm{ml} / 1$. In contrast, the least beneficial effects as a result of fertilization treatments were recorded by using the different NPK levels.

\section{b- Chlorophyll (b) content (mg/g f.w.):}

An increment in chlorophyll (b) content in the leaves over control was detected as a result of using the different fertilization treatments. In this regard, applying Grow more at the lowest level $(0.5 \mathrm{ml} / \mathrm{l})$ proved its superiority in increasing chlorophyll (b) giving the utmost high value in this concern. Meanwhile, using the highest level of phosphorene (6 g/pot) achieved the second category in elevating such constituent. The third rank was occupied by plants treated with the moderate level of phosphorene (4 $\mathrm{g} /$ pot) and the highest one of NPK (3.5 $\mathrm{g} / \mathrm{pot})$. The least scores on the other side, were noticed from plants treated with phosphorene at $2 \mathrm{~g} /$ pot and those treated with NPK at 1.5 and $2.5 \mathrm{~g} /$ pot or treated with Grow more at 1.5 and $2.5 \mathrm{ml} / 1$.

\section{c- Carotenoids content (mg/g f.w.):}

Clear differences were noticed in carotenoids accumulation in the leaves, resulted from applying the different fertilization treatments as indicated in Table (5). In this respect, all of them increased such pigment comparing with that gained from control plants. However, applying phosphorene at the highest level $(6 \mathrm{~g} / \mathrm{pot})$ or Grow more at the lowest one $(0.5 \mathrm{ml} / \mathrm{l})$ were the best treatments used in elevating this component in the leaves and occupied the first rank in this regard. The second category was achieved by plants which received the moderate levels of Grow more $(1.5 \mathrm{ml} / \mathrm{l})$. Meanwhile, the third position in raising such constituent was occupied by plants which received the lowest and moderate levels of phosphorene ( 2 and $4 \mathrm{~g} / \mathrm{pot}$ ) and those treated with the highest level of Grow more $(2.5 \mathrm{ml} / \mathrm{l})$. The other treatments, on the other side, gave a moderate effect in this concern.

\section{2- Effect on chemical constituents:}

a- N\%:

As shown from data recorded in Table (5), it is obvious that all fertilization treatments augmented the registered values comparing with that gained from control 
Reem M. Said et al.

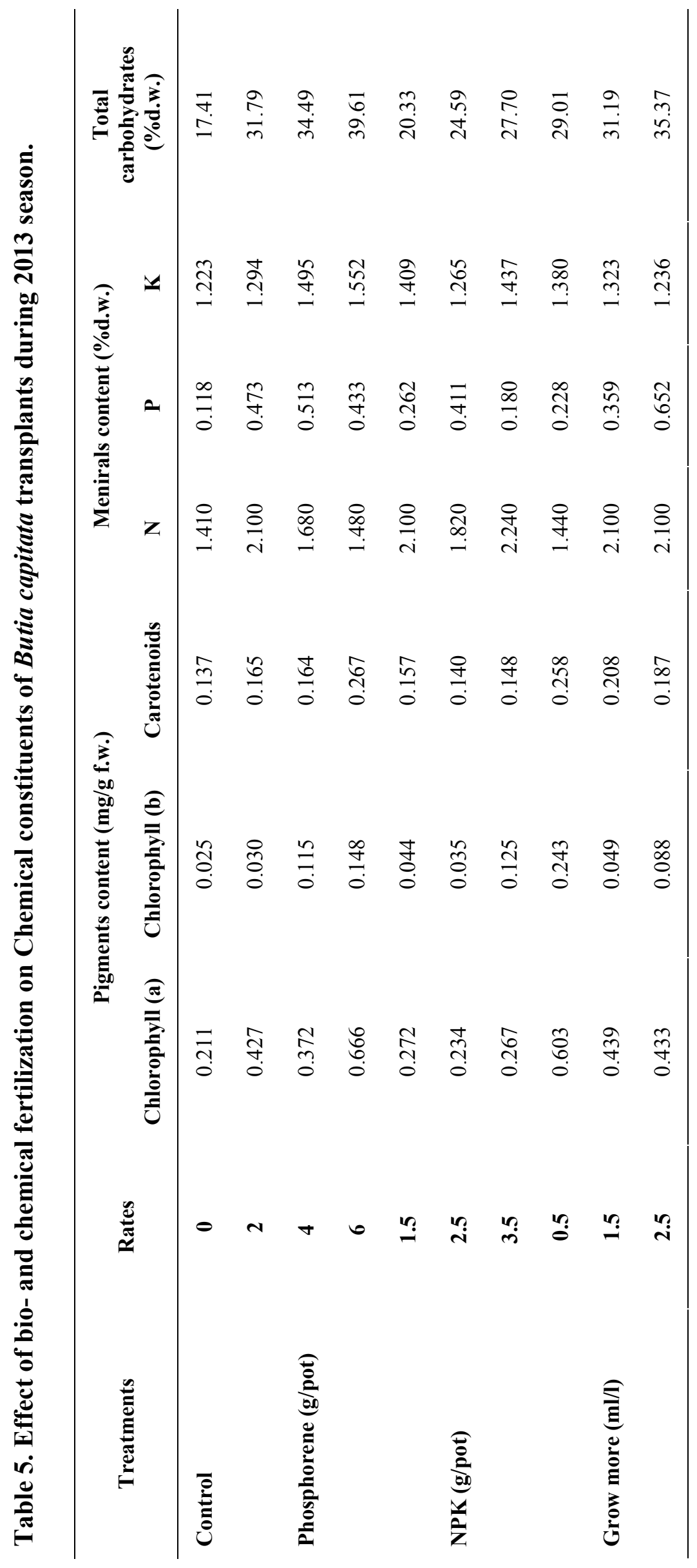


plants. However, data indicated the prevalence of applying the lowest levels of phosphorene and NPK (2 and $1.5 \mathrm{~g} / \mathrm{pot}$, respectively) as well as the highest level of NPK $(3.5 \mathrm{~g} / \mathrm{pot})$ and the moderate and the highest levels of Grow more (1.5 and 2.5 $\mathrm{ml} / \mathrm{l}$, respectively) in giving the utmost high values and occupying the first rank in this regard. Meanwhile, the moderate level of either phosphorene or NPK (4 and $2.5 \mathrm{~g} /$ pot, respectively) achieved the second position in raising the same constituent in the leaves. The least scores, on the other side were obtained as a result of using NPK at $6 \mathrm{~g} / \mathrm{pot}$ and Grow more at $0.5 \mathrm{ml} / 1$.

\section{b- P\%:}

Phosphorus content in the leaves was also affected by fertilization treatments as all of them improved the accumulation rate of such constituent in leaves as indicated in Table (5). In this connection, great influence was observed in raising $\mathrm{P} \%$ in leaves due to using Grow more at the highest level (2.5 $\mathrm{ml} / \mathrm{l}$ ) with achieving the first category in this regard. Meanwhile, the second one was occupied by plants which received phosphorene at $4 \mathrm{~g} /$ pot. However, plants treated with phosphorene at 2 and $6 \mathrm{~g} / \mathrm{pot}$ and those treated with NPK at $2.5 \mathrm{~g} /$ pot also showed a favourable effect in this respect.

\section{c- K\%:}

It is clear from data listed in Table (5) that all fertilization treatments increased to some extent $\mathrm{K} \%$ in the leaves. However, it could be mentioned that applying the moderate and the highest level of phosphorene (4 and $6 \mathrm{~g} / \mathrm{pot}$ ), and the highest level of NPK (3.5 g/pot) were the best treatments used in elevating $\mathrm{K} \%$ in the leaves and achieved the first position in this respect. Meanwhile, treating plants with the lowest level of either NPK or Grow more (1.5 g/pot and $0.5 \mathrm{ml} / 1$, respectively) occupied the second category in raising content of this element in the leaves. In contrast, the least score was confined by plants treated with Grow more at the highest level $(2.5 \mathrm{ml} / \mathrm{l})$ and untreated ones (control).

\section{d- Total carbohydrates\%:}

Data outlined in Table (5) reveal that most fertilization treatments caused a clear increment in total carbohydrates $\%$ in the leaves. However, results considerably differed according to the different treatments used. In this regard, plants which received the highest phosphorene level (6 g/pot) proved its mastery in raising total carbohydrates $\%$ in the leaves and occupied the first rank in this respect. The second rank in elevating such constituent was obtained from applying phosphorene at $4 \mathrm{~g} /$ pot and Grow more at the highest level $(2.5 \mathrm{ml} / \mathrm{l})$. Meanwhile, the third category in raising this constituent was achieved by treating plants with phosphorene at $2 \mathrm{~g} /$ pot and Grow more at $1.5 \mathrm{ml} / 1$. The least score on the other side was obtained by treating plants with NPK at the lowest level.

\section{Effect of bio- and chemical fertilization on chemical constituents of Livistona decipiens leaves (Table, 6):}

\section{1- Effect on pigments content:}

\section{a- Chlorophyll (a) content (mg/g f.w.):}

Chlorophyll (a) content in leaves responded better to the different fertilization treatments which caused an increment in such constituent comparing with that gained from control plants as indicated in Table (6). However, the scored values clearly indicate the superiority of using Grow more at the lowest and moderate levels ( 0.5 and $1.5 \mathrm{ml} / \mathrm{l})$ in elevating chlorophyll (a) content in the leaves and occupied the first rank in this respect. Meanwhile, plants treated with the lowest level of NPK (1.5 g/pot) belonged to the second position in raising the same constituent. In the same time, plants treated with the moderate and the highest level of NPK (2.5 and $3.5 \mathrm{~g} / \mathrm{pot}$ ) achieved the third rank in improving such constituent. In contrast, the least score was confined to plants treated with phosphorene at the moderate level ( $4 \mathrm{~g} / \mathrm{pot})$. 
Reem M. Said et al.

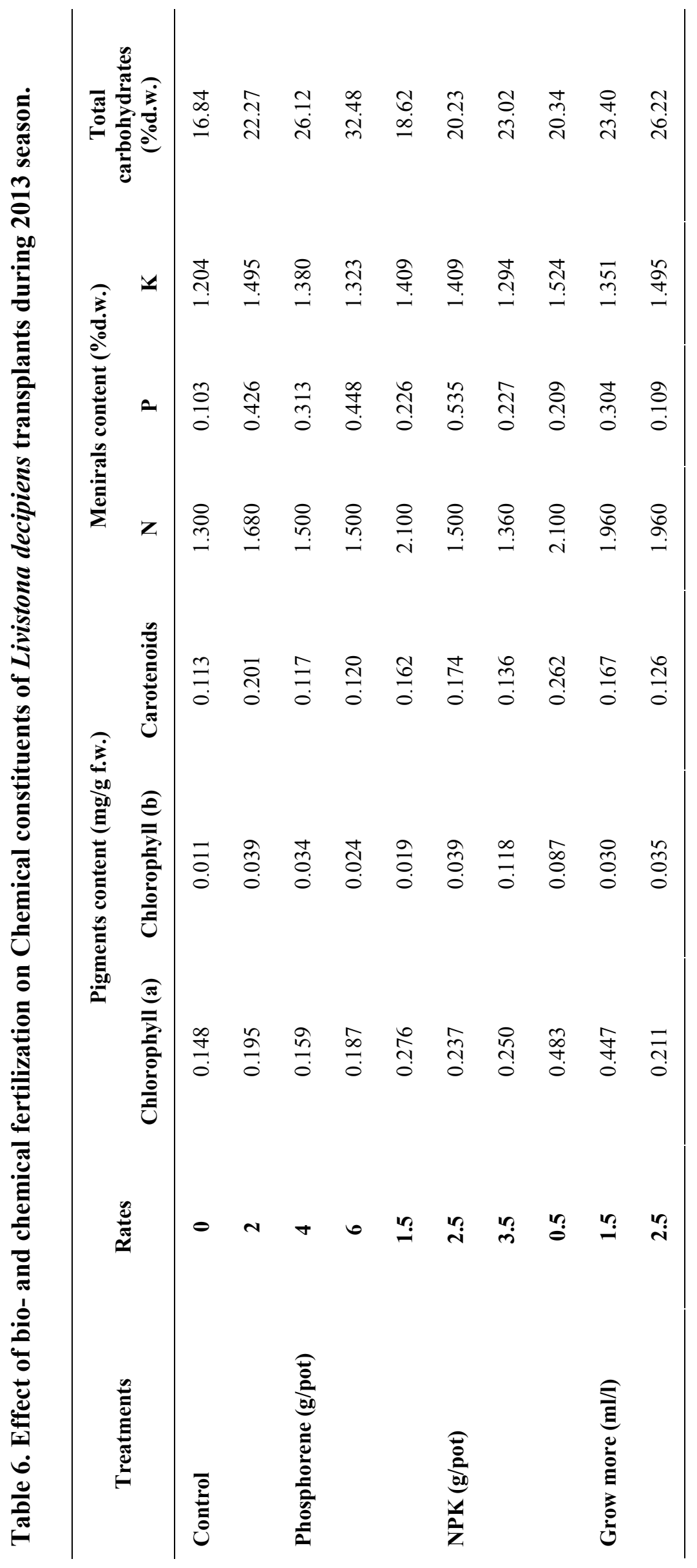




\section{b- Chlorophyll (b) content (mg/g f.w.):}

It is clear from data presented in Table (6) that the different fertilization treatments induced an increment in chlorophyll (b) content in the leaves comparing with that obtained from control plants, but, there were clear differences among the different treatments used. In this connection, applying NPK at the highest level $(3.5 \mathrm{~g} / \mathrm{pot})$ proved its superiority in giving the utmost high value and occupied the first rank in this concern. Meanwhile, plants which received the lowest level of Grow more $(0.5 \mathrm{ml} / \mathrm{l})$ achieved the second position in elevating such constituent. The least record, on the other side, was confined to plants supplied with the lowest level of NPK $(1.5 \mathrm{~g} / \mathrm{pot})$. The other treatments gave an intermediate effect in this regard.

\section{c- Carotenoids content (mg/g f.w.):}

Carotenoids content in the leaves showed an increment comparing with that gained from control plants due to supplying plants with the different fertilization treatments. Using the lowest Grow more level $(0.5 \mathrm{ml} / \mathrm{l})$ proved its superiority in raising carotenoids in the leaves and achieved the first position in this respect. However, supplying plants with phosphorene at the level of $2 \mathrm{~g} /$ pot occupied the second category in elevating such constituent. Meanwhile, the third rank belonged to plants treated with either NPK at 1.5 and $2.5 \mathrm{~g} / \mathrm{pot}$ or with Grow more at $1.5 \mathrm{ml} / 1$. In contrast, the least means were confined to plants treated with phosphorene at either 4 or 6 $\mathrm{g}$ /pot or Grow more at $2.5 \mathrm{ml} / \mathrm{l}$.

\section{2- Effect on chemical constituents:} a- N\%:

Beneficial effects were recorded on $\mathrm{N} \%$ in the leaves due to all fertilization treatments used over the control. In this respect, using the lowest level of NPK (1.5 $\mathrm{g} /$ pot $)$ or Grow more $(0.5 \mathrm{ml} / \mathrm{l})$ registered the utmost high values. However, supplying plants with the moderate and the highest level of Grow more occupied the second position in raising the same constituent. The third rank was belonged to plants treated with phosphorene at the lowest level (2 $\mathrm{g} /$ pot). The least score, on the other side, was achieved by plants that received the highest level of NPK.

b- P\%:

Data presented in Table (6) show that the different fertilization treatments caused an increment in the accumulation rate of $\mathrm{P} \%$ in the leaves. In this respect the utmost high value was obtained by applying the moderate NPK level (2.5 g/pot). Meanwhile, the second category in elevating such element was recorded as a result of fertilizing with the highest phosphorene level (6 g/pot). However, plants dressed with the lowest phosphorene level (2 g/pot) achieved the third position in elevating the same constituent. On the contrary, the least score was obtained as a result of supplying plants with the highest level of Grow more (2.5 $\mathrm{ml} / \mathrm{l}$ ). The other treatments used gave an intermediate effect in this regard.

\section{c- $K \%$ :}

A marked increment was observed in the leaf content of $\mathrm{K}$ due to applying the different fertilization treatments in most cases. In this connection, treating plants with phosphorene at $2 \mathrm{~g} /$ pot and Grow more at 0.5 $\mathrm{ml} / 1$ and $2.5 \mathrm{ml} / 1$ succeeded to produce the highest accumulation rate of $\mathrm{K} \%$ in the leaves occupying the first rank in this regard. Meanwhile, plants fertilized with NPK at 1.5 and $2.5 \mathrm{~g} /$ pot achieved the second rank in raising $\mathrm{K}$ content. The third position was attained by plants which received phosphorene at 4 and $6 \mathrm{~g} /$ pot and Grow more at $1.5 \mathrm{ml} / 1$. In contrast, the least score resulted from using the highest level of NPK at $3.5 \mathrm{~g} /$ pot.

\section{d- Total carbohydrates\%:}

Results presented in Table (6) reveal an increment in total carbohydrates $\%$ in the leaves resulting from supplying plants with the different fertilization treatments comparing with that registered from control plants. However, the effect of fertilization treatments considerably differed among the 
different treatments. In this respect, the greatest value was obtained due to applying phosphorene at $6 \mathrm{~g} /$ pot treatment which occupied the first rank in this regard. The second position was occupied by plants treated with phosphorene at $4 \mathrm{~g} /$ pot and Grow more at the highest level $(2.5 \mathrm{ml} / \mathrm{l})$. Meanwhile, plants which received phosphorene at $2 \mathrm{~g} /$ pot and those received Grow more at $1.5 \mathrm{ml} / 1$ were belonged to the third position in this regard. In contrast, the least score was obtained as a result of supplying plants with NPK at $1.5 \mathrm{~g} /$ pot.

The previous results that bio- and chemical fertilization revealed a marked influences on chemical constituent of leaves of both palm plants, as they improved chemical constituents in the leaves of treated plants comparing with those gained from untreated plants. However, such effect was ascertained by many researchers on different plants. In this connection, Hassan and AbouRayya (2003) stated that phosphorene was effective in improving nutritional status and leaf pigments content of Anna apple trees. Gobara (2004) reported that different concentrations of algae extract improved the content of $\mathrm{N}$ in the leaves of date palm. Saher (2008) on jojoba seedlings concluded that Biomagic application and bacterial inoculation (Azotobacter and Bacillus) significantly increased leaves, shoots and roots content of mineral elements as compared with control. Osman (2010) on one year-old two olive cultivars, revealed that bio- and NPK fertilizer treatments significantly increased mineral contents, shoot nitrogen and $\mathrm{C} / \mathrm{N}$ ratio by kotengin + biofertilizer $+\mathrm{K}_{2} \mathrm{SO}_{4}$. El-Khateeb et al. (2010) on Chamaedorea elegans concluded that using mycorrhizae at $5 \mathrm{~g} /$ pot was the most effective treatment on increasing chlorophyll $\mathrm{a}$ and $\mathrm{b}$ contents in addition to nitrogen percentage in the leaves. El-Attar (2011) indicated that all biofertilizer treatments (hemogreen, algae, nitrobactrene and mycorrhizae) increased the content of chlorophyll in the leaves. Mycorrhizae and hemogreen treatments gave the highest contents of carbohydrates, N, P and $\mathrm{K}$ in the leaves. Treating Caryota mitis with phosphorene was the best for the content of chlorophyll, $\mathrm{K}$ and carbohydrates in the leaves. Hashish (2011) investigated the effect of bio- and NPK fertilizers on Paulownia kawakamii seedlings. He found that microbein peatmoss $+75 \mathrm{~g}$ NPK significantly increased carbohydrates, $\mathrm{N}$ and $\mathrm{K}$ percentage in the leaves. Meanwhile, microbein peatmoss $+50 \mathrm{~g}$ NPK improved K content in stems and chlorophyll $\mathrm{a}, \mathrm{b}$ and carotenoids contents in the leaves. With regard to the beneficial effects of chemical fertilization on chemical constituents of palm plants and others. Heider (2010) on Dracaena marginata mentioned that Kristalon at 1, 2 and $4 \mathrm{~g} /$ plant increased leaves and stems contents of $\mathrm{N}, \mathrm{P}$ and $\mathrm{K}$. Habib (2012) on Caryota mitis Lour. reported that using NPK at any rate (2 or 4 $\mathrm{g} /$ pot) significantly increased chlorophyll a, $b$ contents, enhanced the accumulation of carbohydrates and raised the value of $\mathrm{K}$ in the leaves. Whereas, Caryota mitis seedlings fertilized with $4 \mathrm{~g}$ /pot NPK contained the highest values of $\mathrm{N}$ and $\mathrm{P}$ content in the leaves.

\section{REFERENCES}

Abd-Rabou, F.A. (2006). Effect of microbine, phosphorene and effective micro-organisms (EM) as biostimulants on growth of avocado and mango seedlings. Egypt. J. Appl. Sci., 21(6B):673-693.

Agina, E.A.M.; Shalaby, H.S.; El-Khayat, A.S. and Korkar, H.M. (2005). Effect of foliar fertilization and some growth regulators on growth and chemical composition of some ornamental plants. Proc. $6^{\text {th }}$ Arab. Conf. Hort., March 20-22, Dept. Hort., Fac. Agric., Ismailia, Egypt.

Csirzinsky, A.A. (1999). Yield response of herbs to $\mathrm{N}$ and $\mathrm{K}$ in sand in multiple harvests. J. Herbs. Spices and Medic. Plants, 6(4):11-22.

El-Attar, A.B.E. (2011). Response of Areca lutescens, Caryota mitis and Chamaedorea elegans Palms to 
Nutritional and Irrigation Treatments. Ph.D. Thesis, Fac. Agric., Cairo Univ., Egypt.

El-Khateeb, M.A.; El-Madaawy, E. and ElAttar, A. (2010). Effect of some biofertilizers on growth and chemical composition of Chamaedorea elegans Mart. seedlings. J. Hort. Sci. \& Ornam. Plants., 2(3):123-129.

El-Sayed, B.A.; Shahin, A.M. and Eliwa, N.Y. (2007). How far nitrobien and gibberellic acid can improve growth and chemical composition of Peperomia obtusifolia cv. Variegata (L.) A. Dietr. Transplants?. J. Biol. \& Chem. Environ. Sci., 2(4):167-179.

El-Sayed, B.A.; Ahmed, S.S. and Shahin, S.M. (2010). Response of Vinca rosea cv. Major plant to chemical and biofertilization treatments. J. Biol. \& Chem. Environ. Sci., 5(4):25-38.

El-Shakhs, M.H. (2002). Long term fertilization for some ornamental palm transplants. Egypt. J. Appl. Sci., 17(12):657-682.

Gobara, A.A. (2004). Effect of algae extract and yeast on fruiting of Zaghloul date palms. J. Agric. Sci. Mansoura Univ., 29(9):5209-5220.

Goldacre, P.L. (1961). The indole-3-acetic acid oxidperoxidase of peas. P: 143-147. In R.M. Klein, ed, Plant Growth Regulation Amer. Iowa State Univ. Press.

GRIN (2011). Butia capitata (Mart.) Becc. Germplasm Resources Information Network. http://www.ars-grin.gov/cgibin/npgs/html/taxon.pl?8181.

Habib, A.M. (2012). Effect of NPK and growing media on growth and chemical composition of fishtail palm (Caryota mitis Lour.). Life Science Journal, 9(4):3159-3168.

Hashish, K.I.I. (2011). Effect of Chemical and Biofertilizers on Growth of
Paulownia Seedlings. Ph.D. Thesis, Fac. Agric., Cairo Univ., Egypt.

Hassan, H.S.A. and Abou-Rayya, T.S. (2003). Effect of some biofertilizers on leaf mineral content, yield and fruit quality of Anna apple trees grown under Northern Sinia conditions. Egypt. J. Appl. Sci., 18(5B):559-574.

Heider, M.A.S. (2010). Effect of Chemical Fertilization and Growing Media on Vegetative Growth and Chemical Composition of Dracaena marginata. M.Sc. Thesis, Fac. Agric., Cairo Univ., Egypt. 148 pp.

Herbert, D.; Philips, P.J. and Strange, R.E. (1971). Determination of total carbohydrates. Methods in Microbiology, 5(8): 290-344.

Jackson, M.L. (1973). Soil Chemical Analysis. Prentic-Hall of India Private Ltd. M-97, New Delhi, India: 498 pp.

Jain, V.K. (1983). Fundamentals of Plant Physiology. S. Chand and Company Ltd. Ram Nagar, New Delhi.: 441 pp.

Jaiti, F.M. (2007). Effectiveness of arbuscular mycorrhizal (AM) fungi in the protection of date palm (Phoenixc dactylifera L.) against bayoud disease. Physiological and Molecular Plant Pathology, 71(416):166-173.

Litz, R.E.; Moore, G.A. and Srinivason, C. (1985). In vitro system for propagation and improvement of tropical fruits and palms. Hort. Review, 7:157-200.

Marschner, H. (1995). Mineral Nutrition of Higher Plants. $2^{\text {nd }}$ Ed. P. 75. Academic Press, London.

Mead, R.; Curnow, R.N. and Harted, A.M. (1993). Statistical Methods in Agriculture and Experimental Biology. $2^{\text {nd }}$ Ed., Chapman \& Hall Ltd., London,: 335 pp.

Mohr, M. and Schopfer, P. (1995). Plant Physiology. Springer-Verlag, New York, USA, 112-114 pp. 


\section{Reem M. Said et al.}

Moran, R. (1982). Formula for determination of chlorophyllous pigment extracted with N-N-dimethyl formamide. Plant Physiol., 69:1376-1381.

Osman, S.M. (2010). Effect of mineral, bioNPK soil application of young olive trees and foliar fertilization on leaf and shoot chemical composition. Research J. Agric., and Biological Sci., 6(3):311-318.

Petterson, B.L.; Patrcia, D.O.P. and Armando, R.T. (2008). Effect of foliar and substrate fertilization on lady palm seedlings growth and development. J. Plant Nutrition, 31(7):1313-1320.

Pregl, F. (1945). Quantitative Organic Micro-Analysis, $4^{\text {th }}$ Ed. J. and A. Churchill Ltd., London, 203-209 pp.

Riffle, R.F. and Craft, P. (2003). An Encyclopedia of Cultivated Palms. Timber Press Inc., Portland, Oregon, USA, $528 \mathrm{pp}$.

Saher, S.S. (2008). Effect of Fertilization on Growth and Chemical Composition of Jojopa Plants in Sandy Soil. Ph.D. Thesis, Fac. Agric., Cairo Univ., Egypt, $218 \mathrm{pp}$.
SAS institute Program (1994). SAS/STAT User's Guide: Statistics Vers. 604, $4^{\text {th }}$ Ed., SAS Institute. Inc., Cary, N. C., USA.

Subba Rao, N.S. (2001). Soil Microbiology Science. Publishers, Inc., Enfield, New Hampshire, USA, 407 pp.

Tisserat, B. (1984). Propagation of date palms by shoot tip culture. Hortsci., 19: 230-231.

Watanabe, F.S. and Olsen, S.R. (1965). Test of an ascorbic acid method for determining phosphorus in water and $\mathrm{NaHCO}_{3}$ extracts from soil. Soil Sci. Soc. Amer. J., 29(6):677-678.

Yeonhee, C.; Enah, P. and Maehee, C. (2000). Effect of nitrogen from nutrient solution on the growth of Aster tataricus, Chrysanthemum boreate and Frafugium japonicum. J. Hort. Sci. Tech., 18(1):1417.

$$
\begin{aligned}
& \text { إستجابة جنسين من نخيل الزينة لبعض معاملات التسميد }
\end{aligned}
$$

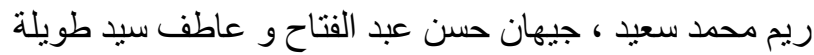

$$
\begin{aligned}
& \text { قسم بحوث الحدائق النباتية ، معهد بحوث البساتين ، مركز البحوث الزئ اعلية ، الجيزة ، الجئة ، مصر. }
\end{aligned}
$$

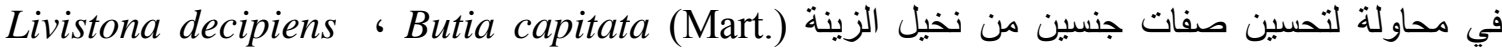
(Becc.)

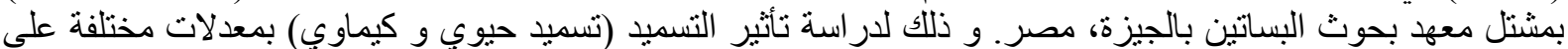

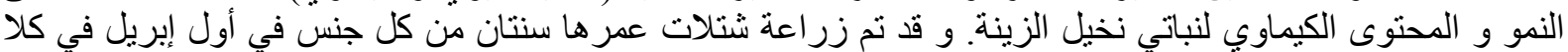

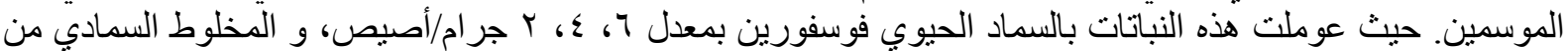

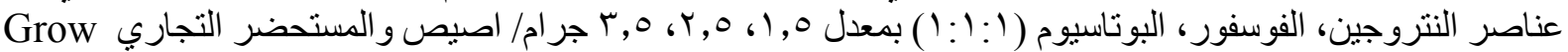

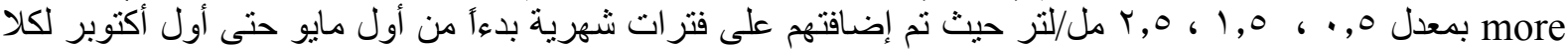
الموسمبن.

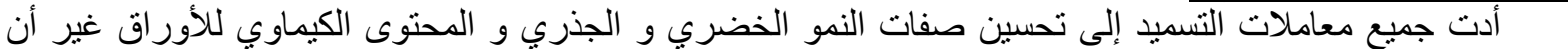

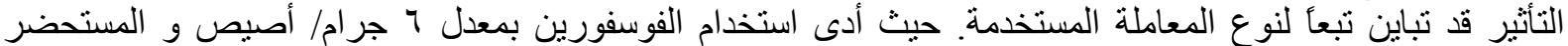

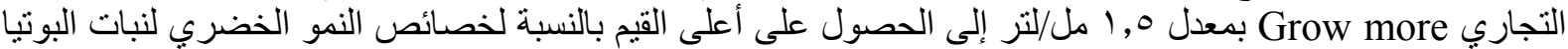

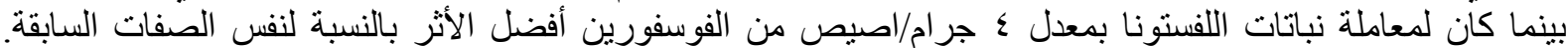

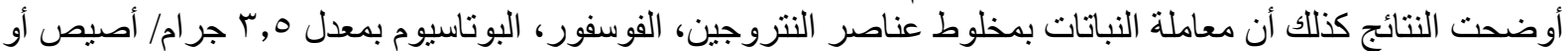

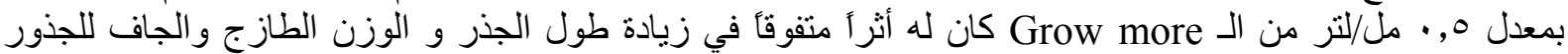

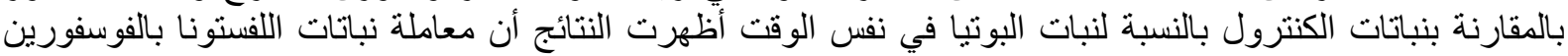


بالمعدل المنخفض (rاجرام/أصيص) كانت أفضل المعاملات التي نم إستخدامها في تحسين خصائص الجذور (عدد

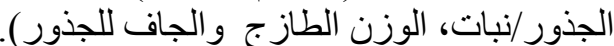
تأثر كذلك المحتوى الكيماوي للأور اق بمعاملاتلات التسميد المختلفة حيث ظهرت زيادة الكياد واضحة في محتوى الأوراق

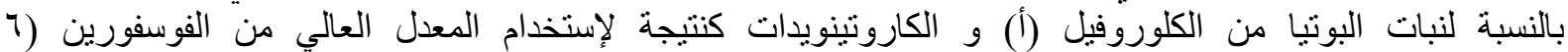

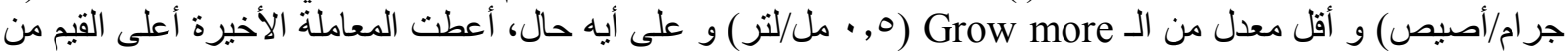

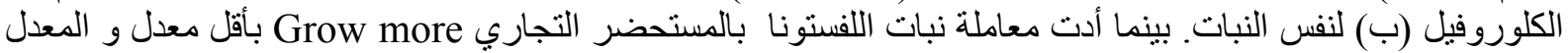

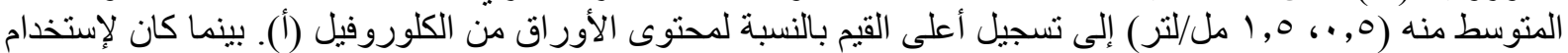

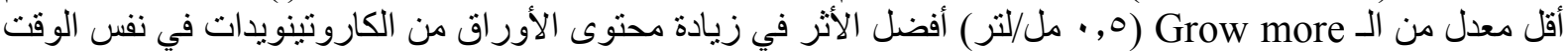

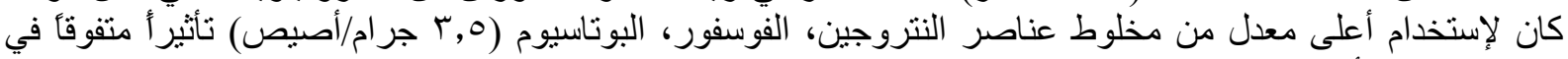

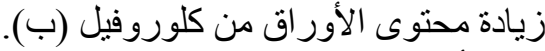

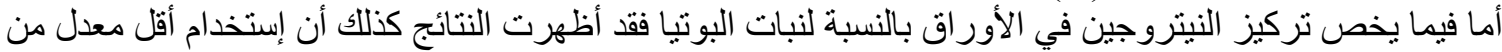

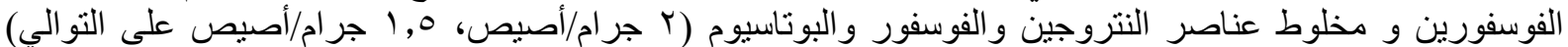

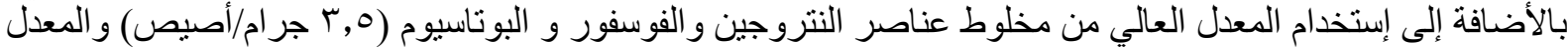

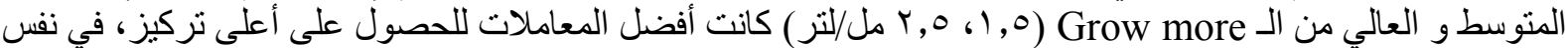

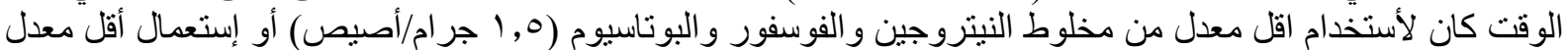

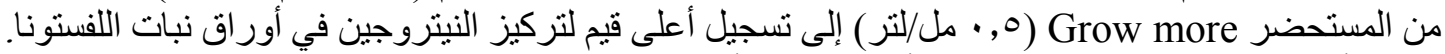

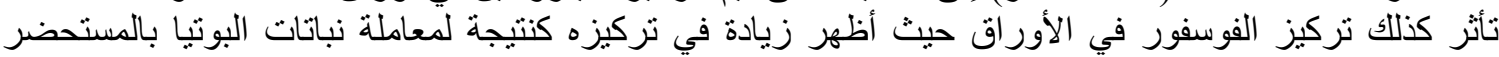
Grow more

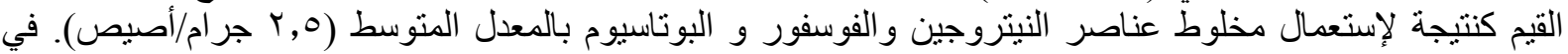

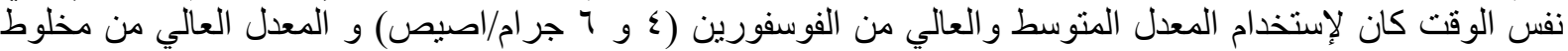

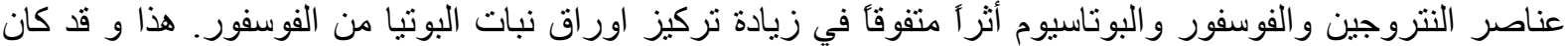

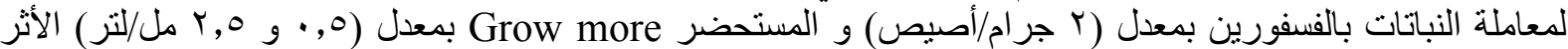

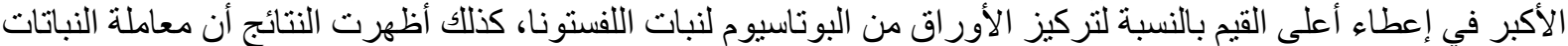

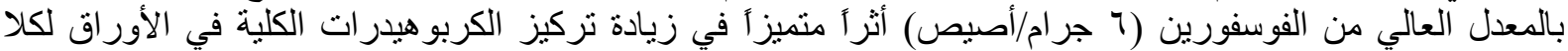

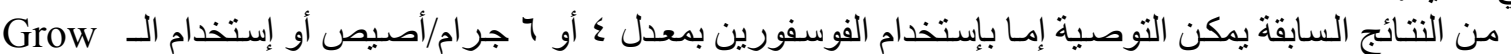

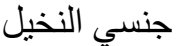

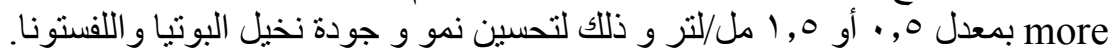


